His published work was not extensive; it included an important article on industrial assurance for students in the Life Assurance Text-Book, which to quite a number of actuaries at that time represented the lifting of the veil that in those days appeared to obscure the essentials of industrial life assurance, and a paper entitled 'On Paid-up Policies and Surrender Values under the Industrial Assurance Acts' (7.I.A. 63, 27I) that was submitted to the Institute in 1932 at the time when the Cohen Committee on industrial assurance was sitting. His outlook was always that of a student and his interest in and advice freely given on the work of his juniors were invaluable. His interventions in debates at Staple Inn Hall were not very frequent but they always showed his capacity to stand back from the problems in hand and to put them in a wider setting of basic principle.

He was one of the few actuaries who have qualified as A.C.I.I. by examination; and in the carly 'twenties, with V. W. Tyler, he lectured for the Insurance Institute of London on new business procedure. This led in 1924 to the publication under their joint authorship of the standard text-book, Life Assurance -from Proposal to Policy, which, in revised editions, remains in the C.I.I. reading to this day.

He gained his Fellowship in 1920 and served on the Board of Examiners from 1927 to 1932 . He served on the Council from 1929 to 1950 . He was for many years a member of the Actuaries' Club and of the Gallio Club and was a founder member of the Fellowship, Denarius and Woolgatherers' Clubs. He was, in fact, the first Chairman of the Woolgatherers, many of whom will remember, with pleasure and profit, his wise remarks at club meetings on a wide variety of non-actuarial subjects. He was a keen freemason, having been Master of Insuranto Lodge in I933. He leaves a widow and two sons, one of whom is a student-member of the Institute.

WILFRED PERKS

\title{
KENNETH JAMES BRITT
}

Kenneth James Britt died on 9 April $x 963$ at the age of $7 x$. He had had a severe cerebral thrombosis in August 1960 and although he fought the effects of that misfortune with characteristic fortitude and determination he never really recovered. He had a further severe attack three or four weeks before he died and after that it seemed fairly certain the end could not be long delayed.

As a boy Britt had had several severe illnesses which confined him to bed for long periods. Inevitably they caused set-backs in his early education but they had their compensations for it was during these periods of illness that he developed a love for serious reading which was to remain with him for the rest of his life.

His first job on leaving King Edward VI's Grammar School, Five Ways, Birmingham, was in the bacteriological department of Bitmingham University, where he had to write out reports on samples which had been the subject of bacteriological examination. He found the work interesting enough, but was not happy with the professor in charge and left after about a year. At the time his brother was with the Yorkshire Insurance Co. Ltd., doing well, and it was thought that the young Britt might well follow his older brother into insurance. 
It was an important decision for it meant that in May 1908 there commenced an association with the Britannic which was to last for over fifty-three years.

Britt very soon came under the influence of the late Murray Laing who encouraged him to take up actuarial examinations. He had a good deal of leeway to make up in his mathematical background. His studies were interrupted by World War I but he qualified as a Fellow of the Faculty in 1922 and as a Fellow of the Institute a year later. 'Thereafter his business life centred round three main interests - his career with his own company and his work for industrial assurance generally, the fulfilment of Bacon's 'debtor to his profession' injunction, and his work for the Chartered Insurance Institute.

His career with his company can be stated quite briefly, for he held successively the positions of Assistant Actuary, Actuary, Director and Vice-chairman. In the sphere of industrial assurance generally he was a member of the Executive of the Industrial Life Offices' Association and served on the actuarial and standing committees. His knowledge was not confined to actuarial matters, for he had had a wide practical experience of life assurance, both ordinary and industrial, in all its aspects.

Britt's work for his profession started soon after he had completed his examinations when he became a tutor for the old Marples classes. These classes, still fondly remembered by many actuaries of an older generation, later became an original part of the official actuarial tuition service. He frequently took part in discussions at the Institute and in 193 I contributed a paper on 'Amalgamations of Life Assurance Companies'. The last time a paper on the subject had been submitted to the Institute was in 1858 so that no one could suggest that Britt's paper was premature and it was warmly welcomed. In 1948 he was elected a member of the Council and for four years did much valuable work in that capacity. For many years he was the official representative in Birmingham of the Institute and the Faculty advising students about the profession.

It is a long way from Birmingham to Edinburgh and it is not surprising that London saw more of Britt than Edinburgh did. Nevertheless he never forgot that he was first of all a Faculty man and he attended sessional meetings in Edinburgh from time to time. In January 1953 he gave a paper entitled 'Industrial Assurance Today', and this was followed in March 1959 by 'Trends in Industrial Assurance'. He enjoyed his visits to the Faculty immensely and always felt very much at home up there. The members themselves were generous and kind and it was, perhaps, the highlight of his professional career when, shortly before his death, he was invited to become one of their vice-presidents.

Britt was a regular attender at International Congresses of Actuaries and from the London Congress of 1927 he missed only one-that held in Holland in 195 I. At the Stockholm Congress in 1930 he contributed a paper on 'Industrial assurance profit sharing in Great Britain' and at the Rome Congress in 1934 a paper jointly with B. C. Lucena on 'The duties and powers of the British Industrial Assurance Commissioner'.

In a memoir for the fournal of the Institute of Actuaries it is natural that the main emphasis should be on the subject's actuarial career but Britt took a wider view of his obligations and played an active and important part in the affairs of the Chartered Insurance Institute. He lectured to local institutes, served on the Instilute Council, on the Examiners Committee and on the Pancl of Moderators which decides on the suitability of the questions themselves. He was prominently associated with the organizing of the tuition and examinations for 
the special certificate for industrial assurance men and was President of the Birmingham Institute during the $195^{-5} \mathrm{I}^{\mathrm{I}}$ session.

In everything he did Britt was a man of tremendous dirive and energy. He worked at great speed and lightly brushed aside all difficulties. He was fearless in the expression of his views and once he had made up his mind that a certain course of action was the right one nothing would turn him from it. He enjoyed his leisure as much as his work. He read widely and had a great love of history. Golf was his game and off his handicap he was a difficult man to beat. He had been President of the Birmingham Insurance Golfing Society and at the time of his death was President of the Industrial I ife Offices Golfing Society. His kind and modest nature was never spoiled by success and it is little wonder that he made friends everywhere. He was particularly happy in his membership of four actuarial dining clubs, the Actuaries', the Gallio, the Denarius and the Faculty of Actuarics (England).

Britt's help and encouragement to younger actuaries extended far beyond the confines of his own office, and the writer was greatly impressed by the concern shown for him during his illness by young actuaries of other offices who spoke with great feeling of all the help they had received from him. It was perhaps this desire to help the younger man which made him such a keen and regular supporter of the Birmingham Actuarial Society. He was one of the founders of the Society and its president in $1932-34$.

During her husband's long illness Mrs Britt had cared for him with untiring love and devotion. She and her son are assured of the warmest sympathy of friends everywhere.

R. B. WALKER 